\title{
OCCUPATIONAL RISK ANALYSIS IN THE POSITION OF A POLICEMAN FROM PATROL AND INTERVENTION LINK - A CASE STUDY
}

\author{
doi: 10.2478/czoto-2021-0011 \\ Date of submission of the article to the Editor: 29/11/2020 \\ Date of acceptance of the article by the Editor: $31 / 03 / 2021$ \\ Marta Jagusiak-Kocik ${ }^{1}$ - orcid id: 0000-0001-6031-9169 \\ ${ }^{1}$ Czestochowa University of Technology, Poland
}

\begin{abstract}
The work presents the assessment of occupational risk using the Risk Score method for the position of a policeman from the Patrol and Intervention Link. A policeman in this position often works in conditions that are not only hazardous to health, but also to life. It patrols streets, buildings, etc. and participates in many interventions. Therefore, it seems important to raise the topic of occupational risk in such a position. By assessing occupational risk using the Risk Score method, threats were identified with the highest risk and activities that may reduce this risk have been indicated.
\end{abstract}

Keywords: occupational risk, stress, policeman, Patrol and Intervention Link, Risk Score method

\section{INTRODUCTION}

The profession of a policeman, despite considerable interest in the labor market, is subject to very rigorous social evaluation. It is a profession classified as professions of public trust, so that each officer should be characterized by high standards, both moral and ethical. Unfortunately, due to the circulating stereotypes, the image of the Police is marked by brutality, awkwardness and ineffectiveness for part of the society. On the one hand, a policeman's uniform often inspires respect. On the other hand, however, any unfortunate actions of the Police (such as the recent events in Poland related to women's strikes) are widely publicized and commented on in the media and very critically received by the public, and unfortunately put the Police in a very unfavorable light.

The profession of a policeman, like any other, has its advantages and disadvantages. Stability of employment and earnings and the possibility of early retirement are the main advantages of this profession. The disadvantage is definitely shift work, policemen have to work on weekends, holidays or at night. This often has an impact on personal life, as this work rhythm makes it impossible to plan private time.

However, the greatest disadvantage of this work is the threats associated with occupational risk. Police officer in his work encounters a lot of stressful situations, often threatening health and life, which makes it necessary to use physical force and 
means of coercion. Other threats are difficult working conditions (regardless of weather conditions, in an environment where there is a possibility of contact with carriers of infectious diseases) and a large number of drastic views. Therefore, every candidate for a job in the Police must be aware that it is not a job, but a service interesting and eventful, but also very stressful and dangerous.

In terms of stressors, the profession of a policeman ranks first among 47 professions selected for the study (Falkiewicz, 2018). After research by the Central Institute for Labor Protection - National Research Institute, over $90 \%$ of the surveyed policemen found work in the Police to be stressful, and over $50 \%$ - that work in the Police and the stress related to it, to a large extent affects family life and personal relationships (Falkiewicz, 2018; Holubova V., 2016; Jasiulewicz-Kaczmarek et al., 2015; Niciejewska and Obrecht, 2020; Zyska and Kiriliuk, 2020).

Stress has many consequences. Among the police officers there are: diseases such as: cardiovascular diseases (hypertension), stomach ulcers, diabetes, neurosis. In addition, policemen complain of insomnia, sleep disorders or low mood. Unfortunately, depression is a common disease.

\section{THE CONCEPT OF OCCUPATIONAL RISK}

Occupational risk is the probability of undesirable events that are related to the work performed and cause losses, in particular, the occurrence of adverse health effects among employees as a result of occupational threats occurring in the work environment or the manner of performing work (Dz.U. $2003 \mathrm{nr} 169$ poz. 1650). Another definition of the occupational risk is the probability of an accident at work or an occupational disease.

The consequences of incidents at the workplace are in the nature of an accident at work, an occupational disease or disease (Woźny, 2020). Occupational risk is defined as health or accident risk. Many factors influence the probability of a particular event occurring, including frequency with which the threat occurs, exposure to the threat, number of people exposed to the threat, possibility of reducing or eliminating the threat. The measure of risk is the determination of the size of losses and the probability of the consequences, such as the number of events or accidents in a given work environment, their severity, health effects, frequency or number of people injured (Krynke, 2020; Niciejewska and Kiriliuk, 2020, Zawieska, 2007).

At each workplace, there are different threats related to occupational risk. The Labor Code imposes obligations on the employer that are related to the occupational risk. Including (Gierasimiuk, 2011, Zawieska, 2007):

- the employer should inform employees about the occupational risk related to the work performed and the principles of protection against threats,

- the employer should assess and document the occupational risk related to the work performed,

- the employer should ensure such conditions of the organization and work stations as to protect employees against accident threats and the effects of factors harmful to health,

- the employer should ensure the elimination of threats to the health and life of employees. 


\section{RESEARCH METHODOLOGY}

The main purpose of the work is to assess the occupational risk in the position of a Patrol and Intervention Link policeman, using the Risk Score method. The assessment was carried out from September to December 2020. The form of obtaining the information necessary for analysis was limited to observing the work of policemen, due to the limitations resulting from the pandemic. There were no direct interviews or expert interviews. There was also no focus on a group from a specific police station, city or province, as it was assumed that police officers from the Patrol and Intervention Link are exposed to similar types of threats, regardless of the region. The assessment presented is therefore a preliminary study. It can be extended to include expert research and surveys among policemen, but due to the prevailing pandemic, these surveys could only be conducted in the form of e-mail sent to a given police station, for example.

The Risk Score (RS) method is also called the risk or time risk indicator method. It is a qualitatively quantitative method (Krause, 2011, Sadłowska-Wrzesińska, 2018, Saja et al., 2017). It develops the definition of occupational risk (Antosz and Miąsik, 2015). This method analyzes the probability of occurrence of adverse events, that are related to the performed work and cause losses, such as adverse health effects for employees. In the Risk Score method, the value of occupational risk is calculated according to the formula (Fine, 1971):

\section{$R=S \times E \times P$}

where (https://allebhp.pl/blogWpis,16, metoda-risk-score.html):

$\mathbf{R}$ - Estimated value of the occupational risk.

S - Effect, loss (potential).

E - Human exposure to danger.

$\mathbf{P}$ - The probability of an event with a given loss.

These three parameters are selected based on specific tables.

The risk value calculated using the formula (1) is read from the risk matrix (https://allebhp.pl/blogWpis,16, metoda-risk-score.html).

\section{OCCUPATIONAL RISK ANALYSIS USING THE RISK SCORE METHOD}

A policeman from the Patrol and Intervention Link performs a patrol and intervention service and his basic tasks include preventing crimes or offenses. Its purpose is to prevent any behavior that poses a threat to the safety of people and property and to prevent behavior that violates public safety and order (and when such events occur to take such measures to restore order and safety). A policeman from the Patrol and Intervention Link should also conduct the necessary preventive actions and maintain contact with the local community to maintain a sense of security. In the occur of an event, which is a prohibited act, a policeman from the Patrol and Intervention Link immediately undertakes actions aimed at identifying and detaining persons suspected of committing this act. He is obliged to arrive at the scene of the incident as soon as possible from the moment of receiving the notification and to secure the place. A policeman from the Patrol and Intervention Link also undertakes order activities (and other actions specified in the regulations) during construction or communication disasters and natural disasters, as well as pursuit actions for the perpetrators of crimes and offenses (Zarządzenie nr 768 Komendanta Głównego Policji). 
Threats included in the occupational risk assessment for the position of a policeman from the Patrol and Intervention Link may appear at any time of its work, even not directly related to its basic duties. For the purposes of the paper, threats are presented typically for related tasks with patrolling the streets and participating in interventions. Occupational risk assessment using the Risk Score method in the position of a policeman from the Patrol and Intervention Link are presented in Table 1.

Table 1

Occupational risk assessment using the Risk Score method in the position of a policeman from the Patrol and Intervention Link

\begin{tabular}{|c|c|c|c|c|c|c|}
\hline $\begin{array}{l}\text { The name of } \\
\text { the threat }\end{array}$ & Cause of the threat & Effect of the threat & $\mathbf{s}$ & $\mathbf{E}$ & $\mathbf{P}$ & $\mathbf{R}$ \\
\hline $\begin{array}{l}\text { Weather } \\
\text { conditions }\end{array}$ & $\begin{array}{l}\text { - High and low } \\
\text { temperatures, } \\
\text { - strong wind, } \\
\text { - rainfall } \\
\text { and snow. }\end{array}$ & $\begin{array}{l}\text { - Colds, } \\
\text { - flu, } \\
\text { - overheating or } \\
\text { cooling down of the } \\
\text { body, } \\
\text { - sunburns. }\end{array}$ & 3 & 2 & 0.5 & 3 \\
\hline Noise & $\begin{array}{l}\text { - Intervention } \\
\text { in a noisy place, } \\
\text { - traffic. }\end{array}$ & - Hearing loss. & 7 & 2 & 1 & 14 \\
\hline $\begin{array}{l}\text { Hitting a falling } \\
\text { object }\end{array}$ & $\begin{array}{l}\text { - Falling parts of } \\
\text { buildings, } \\
\text { - falling objects in } \\
\text { houses, apartments } \\
\text { etc. }\end{array}$ & $\begin{array}{l}\text { - Head injuries, } \\
\text { - limb injuries, } \\
\text { - concussion. }\end{array}$ & 3 & 2 & 0.5 & 3 \\
\hline $\begin{array}{l}\text { Hit } \\
\text { against } \\
\text { stationary } \\
\text { objects }\end{array}$ & $\begin{array}{l}\text { - Various items, tools } \\
\text { etc. indoors and } \\
\text { outdoors. }\end{array}$ & - Whole body injuries. & 3 & 2 & 0.5 & 3 \\
\hline Slips, falls & $\begin{array}{l}\text { - Bad weather } \\
\text { conditions, } \\
\text { - slippery surfaces, } \\
\text { - unsuitable shoes. }\end{array}$ & $\begin{array}{l}\text { - Sprains, dislocations } \\
\text { of the limbs, } \\
\text { - limb fractures, } \\
\text { - contusions of the } \\
\text { whole body. }\end{array}$ & 3 & 2 & 0.5 & 3 \\
\hline $\begin{array}{l}\text { Injury with } \\
\text { sharp objects }\end{array}$ & $\begin{array}{l}\text { - A sharp object } \\
\text { in an invisible place. }\end{array}$ & - Cut and stab wounds. & 3 & 2 & 0.5 & 3 \\
\hline Fire & $\begin{array}{l}\text { - Faulty electrical } \\
\text { installations, } \\
\text { - deliberate activation } \\
\text { by the perpetrator. }\end{array}$ & $\begin{array}{l}\text { - Irritation of the eyes, } \\
\text { respiratory tract, } \\
\text { - light and / or severe } \\
\text { burns of the body, } \\
\text { - death. }\end{array}$ & 15 & 2 & 0.5 & 15 \\
\hline Electric current & $\begin{array}{l}\text { - Faulty electrical } \\
\text { installations. }\end{array}$ & $\begin{array}{l}\text { - Severe burns all over } \\
\text { the body, } \\
\text { - death. }\end{array}$ & 15 & 2 & 0.5 & 15 \\
\hline $\begin{array}{l}\text { Collisions, road } \\
\text { accidents }\end{array}$ & $\begin{array}{l}\text { - Travel by official } \\
\text { means of transport, } \\
\text { - pursuit of the } \\
\text { perpetrator with official } \\
\text { means of transport. }\end{array}$ & $\begin{array}{l}\text { - Light and / or severe } \\
\text { injuries, } \\
\text { - contusions of the body, } \\
\text { - death. }\end{array}$ & 15 & 6 & 3 & 270 \\
\hline Biological & -Contact with the & - Infections with Vidal & 7 & 6 & 6 & 252 \\
\hline
\end{tabular}




\begin{tabular}{|c|c|c|c|c|c|c|}
\hline factors & $\begin{array}{l}\text { infected, } \\
\text { - clearing works, } \\
\text { - securing the accident } \\
\text { places. }\end{array}$ & $\begin{array}{l}\text { hepatitis, HIV, } \\
\text { - coronavirus infection. }\end{array}$ & & & & \\
\hline Physical loads & $\begin{array}{l}\text { - Moving, lifting, heavy } \\
\text { objects, } \\
\text { - lifting, carrying the } \\
\text { perpetrator. }\end{array}$ & $\begin{array}{l}\text { - Injury to the spine, } \\
\text { - joint loads. }\end{array}$ & 3 & 2 & 0.5 & 3 \\
\hline Animal bite & Animals (dog, cat) & $\begin{array}{l}\text { - Bitten wounds, } \\
\text { lacerations. }\end{array}$ & 3 & 2 & 0.5 & 3 \\
\hline $\begin{array}{l}\text { Attack by the } \\
\text { perpetrator / } \\
\text { perpetrators of } \\
\text { the incident }\end{array}$ & $\begin{array}{l}\text { - Intervention in } \\
\text { domestic and public } \\
\text { places, } \\
\text { - Patrolling streets, } \\
\text { buildings, etc. }\end{array}$ & $\begin{array}{l}\text { - Contusions of the } \\
\text { whole body, } \\
\text { - cut and stab wounds, } \\
\text { - gunshot wounds, } \\
\text { - limb fractures, } \\
\text { - death. }\end{array}$ & 15 & 6 & 6 & 252 \\
\hline Drastic views & - Interventions. & $\begin{array}{l}\text { - Stress, } \\
\text { - insomnia, } \\
\text { - depression, } \\
\text { - emotional disorders, } \\
\text { - personal problems. }\end{array}$ & 3 & 3 & 1 & 9 \\
\hline
\end{tabular}

Source: (Own study)

When analyzing the assessment of threats in the position of a police officer from the Patrol and Intervention Link presented in Table 1, it can be concluded that a policeman is exposed to some threats occasionally and these are mainly threats often not directly related to patrolling or interventions, only threats that may also occur in other positions work, e.g. bumps, slips, falls, cuts or physical loads. It was assessed that in the case of such types of threats, the consequences are primarily the absence of a policeman, and the risk value is acceptable.

Changing weather conditions can often be felt during the service. In summer, high positive temperature causes fatigue, weakening of the organism by walking around the area in official uniforms with all service equipment. On the other hand, in winter, climbing stairs often to the last floors in order to intervene in thick uniforms causes an increase in body temperature, and then going outside again causes the opposite effect. This often causes diseases of the upper and lower respiratory tract.

The result of a fire or electric shock threat may even result in death, but statistically, the probability of such an event and the exposure time is negligible, therefore the overall risk value is also small.

The risk values associated with threats directly related to patrolling or interventions are different. On the basis of the analysis, it was found that the highest risk value occurs in the case of the officer participating in a collision or road accident, an officer attacked by the perpetrator or perpetrators of the incident and through the contact with the biological factors. The risk of a traffic accident is possible at every workplace, however, in the work of a policeman, there are chases after the perpetrator or perpetrators of a prohibited act, therefore the risk increases and the value of the risk is high. At almost every home intervention and in public places, an officer is exposed to attack by aggressive, inebriated or intoxicated people. You never know what the behavior of the person or persons participating in the intervention will be. It often 
happens that people who are calm on a daily basis, under the influence of emotions, alcohol, drugs or an intoxicating substance, change their behavior. They become aggressive, provoke verbal skirmishes, and attempt discussions in order to take the officer out of the spotlight. This can result in various injuries, cuts and stab wounds, and unfortunately even death. Occupational risk is also high in the case of a hazard related to contact with biological factors. A policeman is exposed to various pathogens and body fluids when cleaning up and securing the accident places. However, the greatest risk exists when contacting an infected person, who will often injure or bite an officer under the influence of e.g. narcotic drugs, which will significantly increase the risk of infection with a specific pathogen. When performing activities related to personal control, an officer searches the person risk of needle stick injuries or contact with the blood of an infected person to a great extent. Performing these activities is an indispensable element contributing to the safe conduct of an intervention by an officer. Currently, in the assessment of occupational risk, coronavirus infection is also included in the biological factors. A policeman from the Patrol and Intervention Link, who has contact with a large number of people, is more exposed to the risk of infection with this virus.

\section{CONCLUSION}

The work of a policeman from the Patrol and Intervention Link is very stressful work. While performing their daily duties, policemen meet many dangers, most of which negatively affect the body and may pose a threat to health and life.

In the study, using the Risk Score method, the value of risk in the position of a policeman from the Patrol and Intervention Link was assessed. On the basis of the analysis, it was assessed that the highest value of risk occurs when an officer is attacked by the perpetrator or perpetrators of the incident, when interventions at home and in public places, and when in contact with biological factors. It is never possible to predict the course of an intervention, what may happen. There is also a high risk to health and life when an officer is involved in a road accident resulting from the pursuit of the perpetrator or perpetrators of the incident. These threats are inherent in the daily work of each officer working in the Patrol and Intervention Link, because he participates in interventions every day, additionally patrolling his district, taking care of order and security.

In order to minimize the negative effects of threats, it is necessary to carefully analyze the workplace and select appropriate means, i.e. take care o proper organization of work and appropriate selection of personal protective equipment.

In the case of contact with biological factors, officers use protective gloves and masks as well as disinfectants. Knowledge of the operating procedures becomes essential. Protective vaccinations are also a certain protection against certain pathogens. In the era of the coronavirus pandemic, in the National Immunization Program, Police officers were qualified for group I vaccination, which should reduce the risk of contracting coronavirus. In the case of an attack by the perpetrator or perpetrators of a prohibited act, it would be advisable to increase patrols and better protect officers with personal protective equipment. Life and professional experience as well as the ability to properly recognize the situation, taking into account the use of direct coercion measures, play a significant role in reducing this threat. An important element is to exercise extreme caution. These are factors that may or may not reduce occupational risk. 
It is worth mentioning that with every threat, there is stress to a greater or lesser extent. With the threats presented and assessed at work as having the highest risk, stress is greatest. In addition to physical damage to the body, an officer often struggles with sleep disorders, neurosis or even depression due to chronic stress. Unfortunately, a large part of the society is unaware of what a police officer encounters on a daily basis, and how the situations he has to face at work almost every day affect his personal and family life. The social prestige of the profession of a policeman, as a profession of public trust, should be constantly strengthened, as well as should be increase the strength and resources for legal protection of a policeman.

\section{REFERENCES}

Antosz, K., Miąsik, J., 2015. Ocena oraz możliwości minimalizacji ryzyka zawodowego na wybranym stanowisku procesu produkcyjnego, Technologia i Automatyzacja Montażu, 4, 35-40.

Falkiewicz, M., 2018. Stres mundurowy, Szkoła Policji w Katowicach, Katowice.

Fine, W. T., 1971. Mathematical Evaluation for Controlling, Journal of Safety Research, 3(4), 157-166.

Gierasimiuk, J., 2011. Ryzyko zawodowe i zarządzanie bezpieczeństwem i higieną pracy, Politechnika Warszawska Wydział Samochodów i Maszyn Roboczych, Warszawa.

Holubova V., 2016. Integrated Safety Management Systems. Polish Journal of Management Studies, 14, 1, 106-118, DOI: 10.17512/pjms.2016.14.1.10

Jasiulewicz-Kaczmarek, M., Szwedzka, K., Szczuka, M., 2015. Behavior Based Intervention for Occupational Safety - Case Study, Procedia Manufacturing, 3, 4876-4883.

Krause, M., 2011. Praktyczne aspekty doboru metod oceny ryzyka zawodowego, Zeszyty Naukowe Politechniki Śląskiej, 59, 173-190.

Krynke, M., 2020. Risk Management in the Process of Personnel Allocation to Jobs. System Safety: Human - Technical Facility - Environment, 2(1), 82-90, 10.2478/czoto-2020-0011

Niciejewska, M., Kiriliuk, O., 2020. Occupational health and safety management in "small size" enterprises, with particular emphasis on hazards identification, Production Engineering Archives, 26 (4), 195-201.

Niciejewska, M., Obrecht, M., 2020. Impact of Behavioral Safety (Behavioural-Based Safety - BBS) on the Modification of Dangerous Behaviors in Enterprises. System Safety: Human - Technical Facility - Environment, 2(1), DOI: 10.2478/czoto-20200040

Sadłowska-Wrzesińska, J., 2018. Podstawy bezpieczeństwa i zdrowia w pracy, Wydawnictwo WSL, Poznań.

Saja, P., Woźny, A., Pacana, A., Dobosz, M., 2017. Additional components of risk assessment and their impact on the probability parameter, Production Engineering Archives, 14(14), 11-14.

Tytyk, E., 2017. Bezpieczeństwo i higiena pracy, ergonomia i ochrona własności intelektualnej, Wydawnictwo Politechniki Poznańskiej, Poznań.

Woźny, A., 2020. Selected problems of managing work safety - case study. Production Engineering Archives, 26(3), 99-103, DOI: 10.30657/pea.2020.26.20

Zawieska, W.M, 2007. Ryzyko zawodowe. Metodyczne podstawy oceny, CIOP-PIB, Warszawa. 
Obwieszczenie Ministra Gospodarki, Pracy i Polityki Społecznej z dnia 28 sierpnia 2003 r. w sprawie ogłoszenia jednolitego tekstu rozporządzenia Ministra Pracy i Polityki Socjalnej w sprawie ogólnych przepisów bezpieczeństwa i higieny pracy, Dz.U. 2003 nr 169 poz. 1650.

Zarządzenie nr 768 Komendanta Głównego Policji z dnia 14 sierpnia 2007 r. w sprawie form i metod wykonywania zadań przez policjantów pełniących służbę patrolową oraz koordynacji działań o charakterze prewencyjnym.

Zyska, A., Kiriliuk, O., 2020. Influence of Life Style on Safety and Work Efficiency. System Safety: Human - Technical Facility - Environment, 2(1), 62-72, DOI: 10.2478/czoto-2020-0009

https://allebhp.pl/blogWpis,16,metoda-risk-score.html

https://www.ciop.pl/

https://www.pip.gov.pl/pl/bhp/ocena-ryzyka-zawodowego/o-ocenie-ryzykazawodowego/6256,o-ocenie-ryzyka-zawodowego-informacja-wprowadzajaca.html 